\title{
IMPLEMENTASI STRATEGI GO DIGITAL SEBAGAI PEMULIHAN BISNIS UMKM PADA SITUASI PANDEMI COVID-19
}

\author{
Nurul Ainia 1 \\ Nurul Samiatus $\mathbf{S}^{2}$ \\ Sekolah Tinggi Agama Islam Al-Fitrah Surabaya, Indonesia. ${ }^{1}$ \\ Email:nurulainia@gmail.com¹,nurulsamiatuss@gmail.com²
}

\begin{abstract}
Introduction: This study aims to identify and analyze strategies to improve the economy of SMEs that have been implemented due to the impact of the Covid-19 pandemic.

Methods: The research method used is descriptive qualitative method

Results: The results obtained from this study indicate strategies that can be implemented by MSMEs in Kewall, namely changing the sales model to online or e-commerce, conducting digital marketing and building a branding to introduce their products, improving product and service quality for convenience and creating relationships with the community.

Conclusions and suggestions: Strategies that can be implemented by SMEs in Kewall are changing the sales model from conventional to online or e-commerce, doing digital marketing and building a branding to introduce their products.
\end{abstract}

Keywords: Covid 19, SMEs, Go Digital, CRM.

\section{PENDAHULUAN}

Pandemi Covid-19 merupakan virus corona yang berasal dan pertama kali muncul dari kota wuhan, China pada akhir desember 2019. Di duga Covid-19 ini berasal dari hewan kelelawar dan setelah ditelusuri, orang-orang yang terinfeksi virus ini merupakan orang-orang yang memiliki riwayat telah mengunjungi pasar basah makanan laut dan hewan lokal di Wuhan, China. ${ }^{1}$

Terlebih lagi penyebaran virus Covid-19 yang sangat cepat ke negara-negara lainya termasuk Indonesia juga memperparah keadaan ekonomi. Pasalnya pemerintah telah mengeluarkan sejumlah kebijakan yang digunakan untuk memutus rantai penyebaran virus seperti pembatasan sosial dan penutupan sejumlah perusahaan yang membuat masyarakat membatasi tingkat konsumsinya karena minimnya pemasukan

\footnotetext{
${ }^{1}$ Eman Supriatna, "Wabah Corona Virus Disease Covid 19 Dalam Pandangan Islam," dalam Jurnal Sosial \& Budaya Syar'I, (No. 01,Vol. Juni 2020), 46.
} 
atau bahkan sama sekali tidak ada pemasukan sementara kebutuhan sehari-hari terus berjalan. Sejumlah kebijakan dikeluarkan untuk meringankan beban rakyat termasuk pemberian subsidi listrik dan pemberian bantuan tunai setiap bulannya. Hal ini membuat anggaran negara yang terus berkurang sementara tidak ada pemasukan yang membuat negara melakukan hutang dalam jumlah besar termasuk meluncurkan global kupon bon guna menstabilkan keadaan perekonomian di Indonesia. ${ }^{2}$

International Monetary Fund (IMF) mecatat bahwa ekonomi global akan berada pada tingkat minus 2\% sebagai akibat dari adanya pandemi Covid-19 yang menjadi wabah di seluruh Dunia yang menyebabkan kontraksi perekonomian Dunia mencapai titik minus, dengan angka sebelum adanya pendemi Covid-19 mencapi 2,9\%. Laporan Organisastion for Economic Co-Operation and Development (OECD) mengatakan bahwa virus corona secara aktif terlibat memberikan ancaman krisis ekonomi global yang dapat ditandai dengan pemberhentian aktivitas produksi, menurunnya bursa saham secara signifikan, hingga tingkatekonomi masyarakat yang merosot. OECD memprediksi apabila keadaan ini berlangsung secara terusmenerus, maka akan menyebabkan menurunnya tingkat output di berbagai Negara. ${ }^{3}$

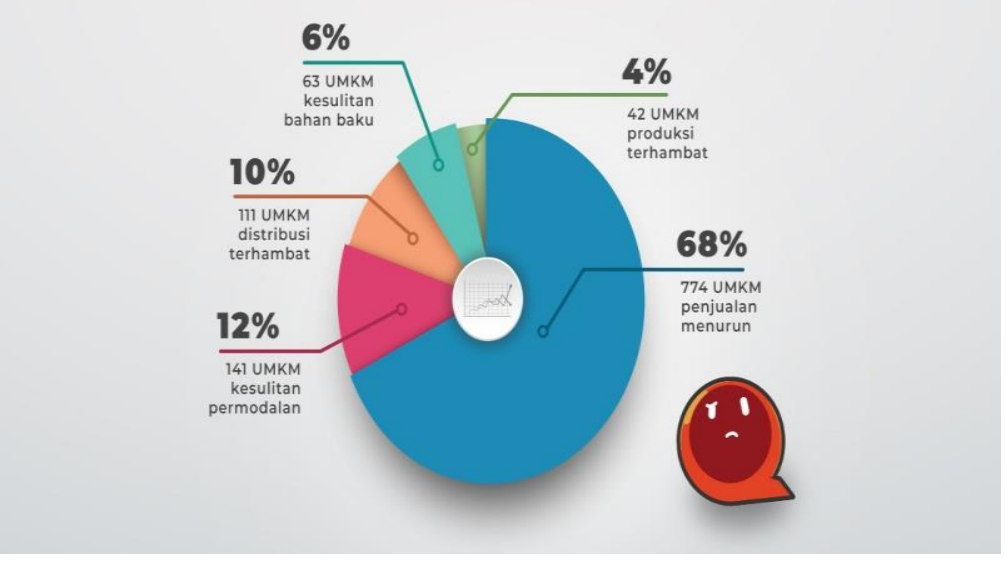

Sumber data: Kemenkop UMKM, 2020

Usaha kecil dan menengah (UMKM) berada di garis depan guncangan ekonomi yang disebabkan oleh pandemi Covid-19. Langkah-langkah penguncian (lockdown) telah menghentikan aktivitas ekonomi secara tiba-tiba, dengan penurunan permintaan dan mengganggu rantai pasokan di seluruh dunia. Dalam survei awal, lebih dari 50\% UMKM mengindikasikan bahwa mereka bisa gulung tikar dalam beberapa bulan ke depan. Sejak itu, kebangkrutan telah menumpuk dan tingkat awal mulai runtuh. ${ }^{4}$ Hal tersebut

\footnotetext{
${ }^{2}$ Sumadi, Menakar Dampak Fenomena Pandemi Covid-19 Terhadap Perbankan Syariah, dalam Jurnal hokum Ekonomi Syariah, (No. 2, Vol. 3 Oktober 2020), 147.

${ }^{3}$ Fadilah Nur Azizah, Igo Fadilah Ilham, Liza Putri Aqidah, Safira Aliyani Firdaus, Setyani Agung Dwi Astuti dan Imam Buchori, "Strategi UMKM untuk Meningkatkan Perekonomian selama Pandemi Covid-19 pada saat New Normal", dalam OECONOMICUS Journal of Economics, (No. 1, Vol. 05, December 2020), 48.

${ }^{4}$ Abdurrahman Firdaus Thaha, "Dampak Covid-19 Terhadap Umkm Di Indonesia", dalam Jurnal Brand, (No. 1,Vol. 02, Juni 2020), 148.
} 
ditunjukkan dengan adanya penurunan omzet, penurunan order, dan penurunan pendapatan serta kendala-kendala lain terkait dengan kegiatan usaha seperti proses produksi, pemasaran, dan distribusi. Para pelaku UMKM mengharapkan adanya bantuan dana/modal usaha, pemasaran produk, dan kebutuhan pokok. Mereka juga membutukan alat-alat kesehatan yang dapat mendukung proses produksi selama pandemi Indonesia. Guna mengurangi kontak fisik dalam bisnis digital menjadi salah satu solusi, tentunya dengan tetap menyesuaikan dengan penerapan adaptasi kebiasaan baru. ${ }^{5}$

Tak dapat dipungkiri, perlahan semua sudah beralih ke arah digital, sehingga interaksi antara manusia dan teknologi sudah tidak terelakkan lagi. Semua pemenuhan kebutuhan sudah tesedia secara digital, mulai dari jual beli, jasa, hingga transaksi pembayaran. Pemanfaatan teknologi merupakan dasar dari masing-masing revolusi industry. Dampak era revolusi industry 4.0 adalah teknologi digital yang digunakan memungkinkan terjadinya intekoneksi antara mesin fisik dengan system produksi.teknologi menjadi unsur utama tehadap pengembangan industri konvensional menuju industri digital sehingga mampu mentransfer data tanpa bantuan manusia serta dengan adanya big data agar mampu membantu dalam menentukan arah dalam bisnis. ${ }^{6}$

Berdasarkan latar belakang permasalahan yang telah diuraikan di atas, maka dapat dirumuskan bahwa permasalahan dalam penelitian ini, yaitu Apakah dampak dari diberlakukannya kebijakan dari pemerintah bagi UMKM? dan Bagaimanakah strategi yang dapat dilakukan oleh UMKM dalam meningkatkan perekonomian akibat pandemi Covid-19? Sedangkan tujuan dari penelitian ini yaitu untuk Adapun maksud dari penelitian ini yaitu untuk menemukan dan melakukan analisis dampak yang diakibatkan dari adanya kebijakan dari pemerintah bagi UMKM serta mengetahui strategi yang dapat dilakukan oleh UMKM dalam meningkatkan perekonomian selama pandemi Covid-19. Adapun manfaat yang dapat diperoleh dari paper penelitian ini yaitu dapat memberikan kontribusi yang bermanfaat dan praktis guna menambah wawasan, menjadi referensi tambahan serta dapat dijadikan sebagai bahan acuan pada penelitian mendatang untuk mengembangkan ilmu pengetahuan khususnya di bidang akuntansi bagi para pelaku usaha UMKM dalam menjalankan bisnisnya di tengah wabah Covid-19. Pembatasan dalam penelitian ini dibuat berdasarkan pada tingkat urgensi atau kepentingan dengan permasalahan yang dihadapi, yaitu difokuskan pada "Implementasi strategi go digital sebagai pemulihan bisnis umkm pada situasi pandemi Covid-19.

\footnotetext{
${ }^{5}$ Luki Masriansyah, "Go Digitial and Customer Relationship Marketing sebagai Strategi Pemulihan Bisnis UMKM yang Efektif dan Efisien di Masa Adaptasi New Normal" dalam Program Studi Magister Manajemen Fakultas Ekonomi dan Bisnis

${ }^{6}$ Rahmi Rosita, "Pengaruh Pandemi Covid-19 Terhadap Umkm Di Indonesia", dalam Jurnal Lentera Bisnis, (No. 2, Vol. 09, November 2020), 110.
} 


\section{TINJAUAN PUSTAKA}

\section{Covid-19}

Covid-19 merupakan wabah baru yang muncul di akhir tahun 2019. Wabah ini berasal dari Wuhan, China pertama kalinya. Wabah kali ini termasuk virus yang sangat berbahaya di karenakan virus yang tidak terlihat dan dapat mematikan banyak orang. Adanya virus ini tidak hanya berdampak pada kesehatan, melainkan juga kepada beberapa sektor di seluruh dunia. Bahkan sampai saat ini vaksin guna menangkal virus Covid-19 belum ditemukan. ${ }^{7}$ Meskipun angka kesembuhan Covid-19 terus meningkat, kemunculan kasus penyebaran Covid-19 juga mengalami peningkatan sehingga ketidakpastian masih terus memengaruhi laju perekonomian global. Moody's Investor Service memprediksi pertumbuhan ekonomi Indonesia pada tahun 2020 akan mengalami perlambatan pada angka 4,8\% terhadap Produk Domestik Bruto (PDB). Nilai ini di bawah pertumbuhan tahun 2019 yang berada di angka 5,02\%. Perlambatan ekonomi ini diperkirakan akan berlanjut di tahun 2021 meski dengan disertai sedikit penguatan yaitu tumbuh 4,9\% saja. Dalam situasi krisis seperti ini, sektor UMKM sangat perlu perhatian khusus dari pemerintah karena merupakan penyumbang terbesar terhadap PDB dan dapat menjadi andalan dalam penyerapan tenaga kerja, mensubtitusi produksi barang konsumsi atau setengah jadi. $^{8}$

\section{UMKM}

Di Indonesia, definisi UMKM diatur dalam Undang-Undang Republik Indonesia No.20 Tahun 2008 tentang UMKM. Pasal 1 dari UU terebut, yang mana pasal tersebut menyatakan bahwa Usaha mikro adalah usaha produktif milik orang perorangan dan/atau badan usaha perorangan yang memiliki kriteria usaha mikro sebagaimana diatur dalam UU tersebut. Usaha kecil adalah usaha ekonomi produktif yang berdiri sendiri, yang dilakukan oleh orang perorangan atau badan usaha yang buka yakni anak perusahan atau bukan anak cabang yang dimiliki, dikuasai atau menjadi bagian, baik langsung maupun tidak langsung, dari usaha menengah atau usaha besar yang memenuhi kriteria usaha kecil sebagaimana yang dijelaskan dalam UU tersebut. ${ }^{9}$ Kegiatan UMKM meliputi berbagai kegiatan ekonomi, namun sebagian besar berbentuk usaha kecil yang bergerak disektor pertanian. UMKM juga mempunyai peran yang strategis dalam pembangunan ekonomi nasional, oleh karna itu selain berperan dalam pertumbuhan ekonomi dan penyerapan tenaga kerja juga juga berperan dalam pendistribusian hasil hasil pembangunan. ${ }^{10}$ KEMENKOP UMKM akan menggandeng pelaku usaha yang berbasis online antara: Pertama, salah satu Langkah yang diambil oleh Gojek Grup yakni lebih maju dengan menyediakan ekosistem terlengkap yang lebih dari sekadar teknologi. Salah

\footnotetext{
${ }^{7}$ Khofifah Nur Ihza, Dampak Covid-19 Terhadap Usaha Mikro Kecil dan Menengah (UMKM), dalam Jurnal Inovasi Penelitian, (No.7, Vol.1 Desember 2020). 26.

${ }^{8}$ Maya Intan Pratiwi, "Dampak Covid-19 Terhadap Perlambatan Ekonomi Sektor UMKM" dalam Jurnal Ners, (No. 2 Vol. 04, April 2020), 31.

9 Tulus T.H. Tambunan, UMKM di Indonesia, (Bogor: Ghalia Indonesia, 2009), 16-19.

${ }^{10}$ Sukirno S, Makro ekonomi Teori Pengantar, (Jakarta: Rajawali Pers, 2016), 25.
} 
satunya, menambahkan keterampilan para pelaku UMKM kuliner lewat platform edukasi dan berjejaring (networking), sehingga mereka memperoleh pengetahuan lebih dalam tentang berbisnis, langsung dari sesama pelaku usaha, Kedua Go Food bisa memulai dengan membangun dapur bersama, yang dapat membantu mitranya, yaitu pelaku UMKM, agar lebih meringankan biaya produksinya. GoFood dari awal berdiri berkomitmen untuk meningkatkan skala bisnis para pelaku usaha UMKM kuliner. Kini kami mengambil satu langkah lebih maju dengan menyediakan ekosistem terlengkap yang lebih dari sekadar teknologi, menghimpun arus permintaan dengan ekspansi layanan dan kategori makanan yang disesuaikan dengan perilaku baru masyarakat saat ini pandemi covid $19 .^{11}$

\section{Strategy E-Marketing}

Menurut Chaffey, e-marketing memiliki cakupan yang lebih luas karena mengacu kepada penggunaan berbagai teknologi untuk mencapai tujuan pemasaran dan memiliki perspektif internal dan eksternal. E-marketing merupakan bagian dari e-business yang berorientasi kepada pelanggan. E-marketing adalah proses membangun dan memelihara hubungan dengan pelanggan melalui aktifitas online. Secara singkat, e-marketing dapat diartikan sebagai proses pemasaran secara online untuk memasarkan barang dan jasa serta bertujuan untuk membangun, mempertahankan hubungan dan memberikan kepuasan pada pelanggan. Strategi pengembangan e-marketing dilakukan dalam beberapa tahapan model perencanaan strategi e-marketing sebagaimana yang dijelaskan oleh Strauss dan Frost yaitu: Analisis Situasi, Strategi Perencanaan Marketing, Tujuan, Strategi e-Marketing, Rencana Pelaksanaan, Anggaran, Rencana Evaluasi. ${ }^{12}$

Pelaku UMKM juga dituntut untuk dapat mengkomunikasikan produk secara intensif dengan melakukan pemasaran produk menggunakan digital marketing dan memanfaatkan media sosial untuk dapat menjangkau konsumennya secara langsung dan dapat menekan biaya promosi. Digital marketing merupakan pemasaran yang dilakukan dengan menggunakan akses internet, memanfaatkan sosial media maupun perangkat digital lainnya. Digital Marketing membantu perusahaan atau pelaku usaha dalam mepromosikan dan memasarkan produk dan jasa mereka dan mampu memperluas pasar baru yang sebelumnya tertutup atau terbatas karena adanya keterbatasan waktu, jarak dan cara berkomunikasi, hasil penelitian Hendrawan menyatakan bahwa digital marketing berpengaruh positif dan signifikan terhadap peningkatan penjualan UMKM. ${ }^{13}$

${ }^{11}$ Rema Karyani, Manajemen Kampanye: Paduan Teoritis dan Praktis dalam Mengefektifkan Kampanye Komunikas (Bandung: Aambiosa Rekatam Media, 2004), 19.

${ }^{12}$ Husni Awali dan Farida Rohmah, "Urgensi Pemanfaatan E-Marketing Pada Keberlangsungan UMKM Di Kota Pekalongan Di Tengah Dampak Covid-19" dalam Jurnal Ekonomi dan Bisis Islam, (No. 1, Vol. 2, Janurari - Juni 2020), 6 .

${ }^{13}$ Luki Masriansyah, "Go Digitial and Customer Relationship Marketing sebagai Strategi Pemulihan Bisnis UMKM yang Efektif dan Efisien di Masa Adaptasi New Normal” dalam Jurnal Universitas Tanjungpura, 130. 


\section{METODE PENELITIAN}

Penelitian ini menggunakan metode deskriptif kualitatif, yaitu menggunakan studi pustaka atau literatur yang ada, dengan menggunakan jurnal, buku, dan web yang relevan dengan penelitian. Selanjutnya, data akan disusun dan dianalisis dengan pendekatan analisis deskriptif yang akan menghubungkan faktor-faktor tertentu dengan fenomena yang terjadi saat ini. Metode deskriptif berisi penjabaran setiap tahapan yang dilakukan tanpa melakukan pengujian teori dan menjeneralisasikan. Metode penelitian deskriptif kualitatif ini dilakukan dengan menggunakan sumber data sekunder yaitu studi literatur.

\section{HASIL DAN PEMBAHASAN}

Kota Surabaya tepatnya dikecamatan Tanah Kali Kedinding merupakan wilayah yang strategis dan memiliki potensi untuk dikembangkan secara berkelanjutan dengan tujuan mendukung ekstintensi penegmbangan wilayah kota di masa yang akan datang, diantaranya terdapat berbagai macam tempat wisata yang selalu dipadati oleh wisatawan. Seperti, kawasan kaki jembatan wilayah Suramadu, Pantai kenjeran, dan kawasan tepi pantai di kecamatan Tanah Kali Kedinding. Kawasan ini mempunyai potensi yang besar untuk berkembang sebagai wisata pesisir pantai dan laut. Keberadaan jembatan suramadu dan pantai kenjeran diharapkan dapat memberikan peningkatan potensi dan peran kota Surabaya sebagai pusat kegiatan regional. Disamping itu, kawasan ini memiliki potensi sebagai kawasan untuk kegiatan berdagang dan jasa skala regional.

\section{Dampak Perlambatan Ekonomi Akibat Covid-19 Terhadap UMKM}

Pada tahun 2006-2010 Usaha Mikro Kecil dan Menengah (UMKM) mengalami peningkatan yang menggembirakan dikarenakan UMKM menyumbang sebesar 57\% dari PDB. Dimana UMKM dapat meningkat bukan karena kuantitas melainkan tenaga kerja, modal serta asset mereka. UMKM bisa dikatakan sebagai usaha produktif yang cukup kuat, dimana jika terjadi gejolak atau krisis mereka tidak berdampak dikarenakan prinsip kemandirian yang dimiliki yang artinya mereka tidak bergantung pada lembaga apapun dan memiliki modal sendiri sehingga mereka kokoh sehingga UMKM berperan penting dalam perekonomian. ${ }^{14}$

Dampak dari Covid-19 terhadap UMKM rata-rata mengalami penurunan omset yang lumayan besar. Hal ini terjadi karena berkurangnya aktivitas masyarakat diluar rumah, berkurangnya kepercayaan masyarakat, serta sulitnya memperoleh bahan baku. Salah satunya UMKM Masyarakat Kedinding yang mana UMKM ini, beroperasi sebagai perdagangan biro jasa, contoh : Fotocopy, Agen kosmetik, laundry, serta pedagang kaki lima.

\footnotetext{
${ }^{14}$ Khofifah Nur Ihza, "Dampak Covid-19 Terhadap Usaha Mikro Kecil dan Menengah (UMKM)", dalam Jurnal Inovasi Penelitian, (No.7, Vol.1 Desember 2020), 27.
} 
Tabel 1. Persentase Penurunan Pendapatan Rata-Rata perbulan pada Jenis Usaha Perdagangan

\begin{tabular}{|l|l|c|}
\hline No. & $\begin{array}{c}\text { Sub Klasifikasi UMKM } \\
\text { Kedinding }\end{array}$ & $\begin{array}{c}\text { Penurunan Pendapatan } \\
\text { Rata-Rata perbulan }\end{array}$ \\
\hline 1. & Fotocopy & $-30,15 \%$ \\
\hline 2. & Agen kosmetik & $-40,22 \%$ \\
\hline 3. & Laundry & $-40 \%$ \\
\hline 4. & Aksesoris & $-70,23 \%$ \\
\hline
\end{tabular}

Sumber: Data yang diolah, 2021

Para pengusaha fotokopi melakukan strategi mengurangi jumlah pekerja dan menutup beberapa cabang toko agar bertahan pada masa pandemi. ${ }^{15}$ Sedangkan pengusaha laundry tetap membuka usaha meskipun penjualan rendah, dan strategi yang mereka lakukan yakni memberikan tawaran kepada pelanggan melakukan antar gratis barang pesanan mereka, dan menerapkan pemasaran secara online yakni mempromosikan laundry di sosial media (WhatsApp, Instagram, dan Facebook). ${ }^{16}$

\section{Digital Marketing}

E-Marketing atau Digital Marketing adalah sebuah pemasaran yang memiliki lingkup lebih luas karena mengacu pada media digital seperti web, e-mail dan media nirkabel, tetapi juga meliputi pengelolaan data pelanggan digital, dan juga bagaimana Internet dapat digunakan bersama dengan media tradisional untuk memperoleh dan memberikan layanan kepada pelanggan. ${ }^{17}$ Bisa dikaitkan bahwasannya pemasaran dengan digital marketing mempunyai kaitan yang sangat kuat. jika seseorang mulai mengeksplorasi bisnis pemasaran melalui internet ia akan segera menemukannya bahwa dari pada mencari beberapa pelanggan, dia sekarang akan memiliki kemampuan untuk mencapai jutaan pelanggan dari pendekatan global dan kelompok yang lebih spesifik dan juga dari pelanggan yang lebih dekat dengannya juga, daya tarik juga lebih luas dari pada bisnisnya yang di miliki sebelumnya. Dia bisa menggunakan media sosial sebagai pasar, dan juga memiliki pasar yang ditargetkan.

Dapat disimpulkan bahwasannya tujuan digital marketing akan memberikan dampak yang baik untuk kemajuan perusahaan jika sistem ini bisa dijalankan dengan baik. Berdasarkan pengertian di atas dapat disimpulkan e-marketing adalah proses dan

\footnotetext{
${ }^{15}$ Ardi, Hasil Wawancara dengan owner fotocopy, Surabaya, 02 Mei 2021.

${ }^{16}$ Sulis, Hasil Wawancara dengan owner laundry, Surabaya, 03 Mei 2021.

${ }^{17}$ Chafeey, Mayer, Internet marketing: Strategi, Implementation and Practice, (Jakarta: Prentice hall/finansial times, 2009), 15.
} 
aktivitas pemasaran produk barang dan jasa perusahaan dengan menggunakan media elektronik seperti internet. ${ }^{18}$

Sebagian besar digital marketing bertujuan untuk mencapai berbagai tujuan, seperti: Pertama, Meningkatkan pangsa pasar, Kedua meningkatkan jumlah komentar padasebuah blog atau website, Ketiga Meningkatkan pendapatan penjualan, Keempat Mengurangi biaya, misalnyabiaya distribusi atau promosi, Kelima mencapai tujuanmerek, seperti meningkatkan kesadaran merek, Keenam meningkatkan ukuran database, Ketujuh pencapai tujuan Customer Relationship Management, seperti meningkatkan kepuasan pelanggan, frekuensi pembelian, atau tingkat referensi pelanggan, Kedelapan memperbaiki manajemen rantai suplai, seperti dengan meningkatkan koordinasi anggota, menambahkan mitra, atau mengoptimalkan tingkat persediaan. ${ }^{19}$

Perlu kita ketahui bahwasannya digital marketing dapat bekerja pada bisnis dalam industri apapun, digital marketing masih terlibat dalam membangun buyer personas untuk mengidentifikasi apa yang audience butuhkan, dan membuat nilai konten online. Bagaimanapun, hal tersebut tidak dapat dikatakan bahwa semua bisnis mengimplementasikan strategi digital marketing dengan cara yang sama. ${ }^{20}$

Digital marketing banyak memiliki keuntungan bagi pihak pengusaha, misalnya saja seperti: Pertama, Mampu menghubungkan produsen dengan konsumen melalui internet, kedua Menghasilkan tingkat penjualan yang lebih tinggi karena semakin sempitnya batasan jarak dan waktu, Ketiga Biaya digital marketing jauh lebih hemat daripada biaya iklan di media lain (misalnya cetak, televisi, atau radio), Keempat Digital marketing juga membuat penjual bisa memberikan pelayanan real time kepada pelanggannya. Kelima menghubungkan penjual/pengusaha dengan pelanggannya melalui perangkat mobile dimanapun dan kapanpun. Keenam menghasilkan keuntungan yang jauh lebih besar daripada biaya iklan/promosi yang telah dikeluarkan. Ketujuh membantu menstabilkan posisi sebuah brand/merk di mata konsumen dari merk/brand lain sebagai pesaingnya. Kedelapan membantu para pengusaha mikro untuk mampu bersaing dengan perusahaan makro. Kesembilan mempersiapkan para pengusaha mikro atau pemula terhaadap era internet of things dimana semua hal atau apapun yang diinginkan bisa diperoleh melalui internet. Kesepuluh Memberikan kesempatan yang lebih luas kepada pengusaha untuk melakukan branding terhadap produknya sehingga dikenal dan mendapatkan tempat tersendiri di hati masyarakat. Sehingga masyarakat tidak mudah beralih ke produk lain. ${ }^{21}$

\footnotetext{
${ }^{18}$ Adi Nugroho, E-Commerce Memahami Perdagangan Modern di Dunia Maya, (Bandung: Informatika bandung, 2013), 9 .

${ }^{19}$ M. Suyanto, Strategi Periklanan pada E-Commerce Perusahaan Top Dunia, Yogyakarta: andi. 2003, hal 3132.

20 Mohammed, Internet Marketing: Building Advantage in a Network Economy, New York: McGraw-Hill Companies, 2003, hal 27.

${ }^{21}$ Budi Triyono, Potret Belanja Online di Indonesia, (Jakarta: Pusat Data dan Sarana Informatika, 2013 ), 15.
} 
Kementerian Koperasi dan UMKM mendorong percepatan transformasi digital bagi pelaku UMKM. UMKM yang bertahan diharuskan melakukan adaptasi bisnis dan melakukan inovasi produk, menyesuaikan dengan permintaan pasar. Banyak pelaku UMKM yang berpindah jenis usaha untuk memenuhi kebutuhan makan minuman, kebutuhan pokok, termasuk kebutuhan pribadi, minuman herbal, alat kesehatan termasuk keperluan di rumah Ini yang bisa bertahan. KemenKop UMKM sejak awal membantu adaptasi bisnis. Perilaku konsumen mementingkan barang konsumsi, terutama makanan dan minuman yang bersih dari Covid-19. sehingga kemasan dan pengolahan higenis menjadi sangat penting, dan lebih mementingkan barang konsumsi yang bersih dari Covid-19. Ini terkait kemasan, dan pengolahan secara higenis. Belanja online menjadi tren, standar meningkat. Pihak Kementerian Koperasi dan UMKM akan menjalin kerja sama dengan market online melalui pelatihan-pelatihan, agar semakin banyak pelaku UMKM yang dapat memperluas akses market yang menggunakan digital marketing. Pemanfaatan digitalisasi akan mendorong bisnis menjadi lebih efisien serta akses pembiayaan akan menjadi lebih mudah. Diharapkan GoFood bisa membangun "Rumah Produksi" agar UMKM bisa bersaing dengan pebisnis besar. ${ }^{22}$

Rekam digital akan menjadi pertimbangan untuk mengajukan pembiayaan. Seperti GoFood, yang bermitra dengan UMKM, dengan cash flow yang jelas. Data inilah yang akan memudahkan bank untuk mempertimbangkan dan memberikan pembiayaan. KemenKopUKM sudah lama punya ide untuk mendirikan rumah produksi bersama., hal ini penting, karena UMKM dalam negeri harus bisa bersaing dengan memanfaatkan ecommerce.

\section{Analisis Pemasaran Online dan Digital Branding}

Pengaruh pemasaran online terhadap peningkatan laba UMKM di Kedinding mempunyai pengaruh yang positif. Sistem pemasaran online ini bisa meningkatkan kesejahteraan masyarakat mengingat jumlah pengguna internet di Indonesia juga sangat banyak. Dengan memaksimalkan pemasaran online di bidang UMKM, maka laba penjualan akan semakin meningkat. ${ }^{23}$ Sistem promosi yang mereka gunakan adalah sistem pengiriman berita maupun kupon online. Selain itu mereka juga membuat suatu promosi berupa giveaway dan endorsement. Strategi lain yang diterapkan fullus fashion adalah dengan meningkatkan jenis dan koleksi produk. Hal ini dapat dilihat dari perkembangan toko mereka yang begitu pesat semenjak menambahkan jenis dan koleksi mereka. Selain membuat suatu promosi berupa giveaway dan endorsement, mereka juga memberikan suatu garansi apabila terdapat kesalahan produk saat pengiriman maupun terdapat cacat produk.

${ }^{22}$ Rema Karyani, Manajemen Kampanye: Paduan Teoritis dan Praktis dalam Mengefektifkan Kampanye Komunikasi, (Bandung: Aambiosa Rekatam Media, 2004), 16.

${ }^{23}$ Setiawati, Pengaruh Strategi Pemasaran Online Terhadap Peningkatan Laba Umkm: Strategi Komunikasi Pemasaran, Bandung: Alfabeta, 2017, hal 20. 
Dapat kita ketahui juga bahwa selain kita memaksimalkan system pemasaran online, tentunya kita juga harus membangun merek atau branding. Merek disini juga harus berbasis online atau digital. Dengan membangun merek yang sesuai dengan sistem pemasaran kita, maka produk atau jasa yang kita pasarkan akan lebih mudah dijangkau oleh pembeli. Program branding dan aktivasi merek di era digital menyebutkan bahwa membangun branding digital merupakan hal yang sangat penting untuk diterapkan sehingga akan mendapatkan dampak yang maksimal dan memperluas jaringan. Membangun branding disini juga sangat penting untuk kelangsungan pemasaran di masa depan atau dalam jangka waktu yang lama. Dalam suatu pemasaran online, peran digital branding sangatlah penting karena dengan hal tersebut kita bisa membangun suatu ikatan dengan pelanggan, membuat brand kita menjadi mudah untuk diingat orang, memperluas jangkauan, jaringan dan lain-lain. Digital branding disini bisa berupa logo, website, sosial media dan lain-lain.

\section{Mendeskripsikan Pemasaran Online dan Digital Branding Ditengah Pandemi Covid-19}

Seperti yang telah kita ketahui bersama bahwa pendemi Covid-19 ini telah banyak menimbulkan dampak terhadap pertumbuhan ekonomi yang ada di indonesia. Salah satunya adalah banyaknya para pekerja yang terkena PHK (pemutusan hubungan kerja). Hal ini tentunya akan mempengaruhi roda perekomian kita. Salah satunya yang efektif untuk diterapkan pada masa pandemi ini adalah dengan memaksimalkan pemasaran online dan membangun branding kita. Mengingat semakin banyaknya masyarakat yang memulai WFH (work from home). Dengan demikian peluang untuk memaksimalkan branding maupun pemasaran kita semakin mudah karena penggunaan internet pada saat pandemi Covid-19 meningkat pesat. Dilansir dari situs resmi CNN indonesia, bahwa terjadi peningkatan yang sangat signifikan terhadap pengguna internet di masa pandemi ini.

Salah satu dampak dari gejolak era globalisasi adalah menurunnya peminat pasar tradisional maupun pasar modern terhadap pasar online. Hal ini dikarenakan keuntungan yang di dapat dari pasar online lebih besar dari pada pasar tradisional. Salah satu faktor yang menyebabkan pasar konvensional sepi peminat diantaranya adalah pada faktor kenyamanannya, biaya maupun daya yang tidak terlalu besar, harga yang bersahabat dengan adanya diskon yang menarik serta efisiensi waktu. Hal ini sanga lah cocok untuk ditepkan pada masa pandemi ini mengingat sudah banyak orang yang mempertimbangkankan masalah keamanan maupun kemudahan dalam bertransaksi secara online. Sistem pemasaran online disini tidak ada batasannya, pelanggan bisa memasarkan produk mereka di seluruh penjuru dunia hanya dengan menggunakan 
media internet. Tak lepas dari hal itu untuk memaksimalkan peran pemasaran online harus dibarengi dengan pemantapan digital branding. ${ }^{24}$

Ada beberapa strategi yang bisa di implementasikan oleh UMKM yaitu merubah model penjualan yang semula konvensional menjadi online atau ecommerce, melakukan suatu pemasaran digital dan membangun suatu branding untuk mengenalkan produknya, peningkatan kualitas produk maupun jasa demi kenyamanan serta menciptakan relasi kepada masyarakat maupun pelanggan agar tingkat kepercayaan konsumen meningkat. Jika strategi tersebut dapat diterapkan secara maksimal maka UMKM bisa berjalan dan tidak mengalami kerugian.

Pelaksanaan pemasaran online terhadap pengusah UMKM untuk memasarkan beberapa produknya memberikan dampak yang positif walaupun pada masa pandeminCovid-19 dengan tetap melakukan socialdistancing. optimalisasi pemasaran online di tengah pandemi bisa memberikan solusi kepada seluruh sektor ekonomi karena hal tersebut sesuai dengan konsep revolusi industri 4.0 yang menggunakan teknologi sebagai alat untuk mempermudah pekerjaan. dengan adanya system pemasaran online ini maka permintaan produksi akan tetap berjalan walaupun terhambat oleh Covid-19.25

Implementasi strategi yang dapat diterapkan untuk membangun pamasaran online di tengah atau pasca panedemi ini adalah dengan enerapkan strategi 5Ps yaitu strategi position, plan, prespective, project dan prepare. Dengan menerapkan lima strategi tersebut maka pemasaran online bisa berjalan dengan maksimal pada masa pandemi maupun pasca pandemi dan bisa meningkatkan kepuasan pelanggan. ${ }^{26}$

Strategi digital marketing merupakan strategi yang bertujuan membangun komunikasi antara produsen dan konsumen dan juga untuk membangun kepercayaan pelanggan akan produk yang akan dijual. Jika produk sudah dikenal oleh konsumen maka penjual akan lebih mudah untuk mengembangkan maupun memasarkan produknya. ${ }^{27}$

\section{Perbaikan Kualitas Produk yang Akan Diperjualbelikan Secara Go Digital (Online)}

Ditengah Pandemi Covid-19 ini, konsumen lebih berhati-hati dalam menggunakan barang dan jasa dan terjadi penurunan kepercayaan konsumen terhadap barang dan jasa yang dijual oleh pelaku usaha. Selain itu keterbatasan konsumen dalam melakukan pembelian langsung juga berdampak pada berkurangnya secara signifikan jumlah pembelian konsumen. Untuk itu pelaku UMKM harus melakukan perbaikan kualitas

\footnotetext{
24 Rohimah, "Era Digitalisasi Media Pemasaran Online dalam Gugurnya Pasar Ritel Konvensional. KANAL" dalam Jurnal Ilmu Komunikasi, (No. 6 Vol. Februari 2009), 91.

25 Awali, Rohmah, "Urgensi Pemanfaatan E-Marketing Pada Keberlangsungan UMKM di Kota Pekalongan Di Tengah Dampak COVID-19, Balanca" dalam Jurnal Ekonomi Dan Bisnis Islam, (No. 02, Vol. Januari 2020$), 14$.

${ }^{26}$ Ika Fitriyani, Strategi Manajemen Bisnis Pasca Pandemi Covid-19, (Jakarta: Press 2020),40-48.

${ }^{27}$ Rapitasari, “Digital marketing Berbasis Aplikasi Sebagai Strategi Meningkatkan Kepuasaan Pelanggan” dalam Jurnal Cakrawala, (No.10 Vol Februari 2016), 107-112.
} 
produk untuk dapat meningkatkan kepercayaan konsumen dan secara intensif mengkomunikasikan terhadap kualitas produk. ${ }^{28}$

Peningkatan kualitas produk dan kualitas layanan berpengaruh positif dan signifikan dalam membentuk kepuasan konsumen dan menciptakan loyalitas konsumen bagi pelaku UMKM. Untuk itu pelaku usaha dalam masa pandemik Covid-19 ini perlu untuk memperhatikan dimensi kualitas produk dan memperbaiki produk mereka untuk dapat semakin menambah kepercayaan konsumen. Kualitas produk diartikan sebagai kemampuan dari suatu produk dalam memenuhi kebutuhan dan keinginan konsumen dan Penting untuk UMKM melakukan perbaikan kualitas produk secara berkala dengan menyesuaikan kebutuhan, keinginan dan harapan konsumen. ada delapan dimensi dalam menentukan kualitas produk, yaitu: Pertama, performa/kinerja produk atau seberapa baik produk dapat diukur, Kedua fitur atau atribut tambahan yang melengkapi dan meningkatkan fungsi produk Ketiga kehandalan atau kemampuan produk untuk dapat bertahan dari kemungkinan perubahan lingkungan bisnis pada periode tertentu, Keempat kesesuaian atau seberapa baik produk tersebut sesuai dengan strandar yg ada pada industrinya, Keempat daya tahan atau ketahanan produk dari segi teknis dan nilai ekonomis, Kelima kemudahan perbaikan produk bila terdapat masalah dan dapat segera diperbaiki, Ke enam Estetika produk yaitu bagaimana produk dilihat, didengar atau dirasakan, Ketujuh persepsi terhadap kualitas produk yang mencakup reputasi merek dan faktor lain yang dapat mempengarui persepsi konsumen. ${ }^{29}$

Bentuk peningkatan kualitas produk yang bisa dilakukan adalah melakukan kontrol mutu produk lebih detail dan menjamin kebersihan dan keamanan produk. Selain itu pelaku UMKM dapat menyesuaikan ketahanan produk dan kemasan karena penjualan sekarang lebih sering menggunakan penjualan secara online sehingga daya tahan dan keamanan produk harus lebih ditingkatkan.

\section{Digital Marketing and CRM}

Ditengah pandemi Covid-19 yang dialami di Indonesia khususnya, banyak menurunkan omzet penjualan UMKM. Berkurangnya jumlah konsumen di beberapa sektor dan industri menuntut pelaku UMKM untuk dapat memasarkan produk secara maksimal dan berfikir kreatif dan inovatif. Penggunaan internet pada masa pandemik Covid-19 ini sudah seperti keharusan termasuk dalam menjalankan bisnis dan salah satu upaya dalam memasakan produk yang dapat di adopsi oleh pelaku UMKM adalah dengan melakukan digital marketing. Era digital yang berkembang pesat saat ini tidak mungkin untuk dihindari. Pelaku UMKM harus mampu memaksimalkan manfaat perkembangan digital. ${ }^{30}$

\footnotetext{
${ }^{28}$ Lestari, The Effect Of Product Quality Toward Interest In. Journal of Business Studies (JOBS), (Semarang: Jurusan Administasi Bisnis, Politeknik Negeri Semarang, 2019) 15.

${ }^{29}$ Kotler, Principles of Marketing 15th ed, (New Jersey: Prentice Hall Published, 2012) 20.

${ }^{30}$ Purwana, Pemanfaatan Digital Marketing Bagi Usaha Mikro, Kecil, dan Menengah (UMKM) di Kelurahan Malaka Sari, Duren Sawit. Jurnal Pemberdayaan Masyarakat Madani (JPMM), 2017.
} 
Selain peningkatkan kualitas produk untuk penjualan secara go digital dan layanan online, pelaku UMKM juga dapat meningkatkan kualitas pelayanan dan menambah jenis pelayanan seperti pesan antar dan pelayanan pembelian dengan menggunakan hotline, layanan khusus terkait penjualan yang dapat dengan mudah diakses konsumen UMKM dapat menggunakan delivery produknya secara langsung seperti membuat layanan pesan antar sendiri, atau menggunakan aplikasi seperti Gojek, Grab, Bujang Kurir, dan lain-lain. Dalam melakukan pelayanan pesan antar, pelaku usaha juga lebih memperketat standar pelayanannya dengan meningkatkan dan memastikan kebersihan dari produknya.

Untuk jasa, pelayanan bisa di kembangkan dengan melalui media online dan menggunakan aktifikatas layanan menggunakan daring sehingga bisa lebih efektif dan bisnis bisa berjalan seperti biasa. Pelayanan yang baik akan dapat membentuk kepercayaan konsumen sehingga dapat menciptakan kepuasan pelanggan dan membentuk loyalitas konsumen. Pada masa pandemik ini, kepercayaan konsumen menjadi salah satu faktor penting dalam keberlangsungan usaha.

Customer relationship marketing (CRM) adalah sebuah konsep strategi pemasaran yang berupaya menjalin hubungan jangka panjang dengan para pelanggan, yaitu mempertahankan hubungan yang kokoh dan saling menguntungkan antara penyedia jasa dan pelanggan yang dapat membangun transaksi ulangan dan menciptakan loyalitas pelanggan.

Jadi, CRM berpengaruh positif dan signifikan didalam meningkatkan kinerja pemasaran UMKM melalui peningkatan kualitas hubungan dan orientasi kewirausahaan. Semakin baik kualitas hubungan pelaku UMKM dengan konsumen, pemasok dan yang lainnya, semakin baik kemampuan peningkatan kinerja pemasarannya. Selain itu pelaku usaha yang berani mengambil resiko, sudah memiliki pengalaman dalam bisnis dan fleksibel terhadap bisnis, dapat meningkatkan jejaring dan menumbuhkan kepercayaan dari konsumen, sehingga konsumen akan bertahan.

Covid-19 merupakan wabah baru yang muncul di akhir tahun 2019. Wabah ini berasal dari Wuhan, China pertama kalinya. Wabah kali ini termasuk virus yang sangat berbahaya di karenakan virus yang tidak terlihat dan dapat mematikan banyak orang. Adanya virus ini tidak hanya berdampak pada kesehatan, melainkan juga kepada beberapa sektor di seluruh dunia. Bahkan sampai saat ini vaksin guna menangkal virus Covid-19 belum ditemukan. Dampak dari Covid-19 terhadap UMKM rata-rata mengalami penurunan omset yang lumayan besar. Hal ini terjadi karena berkurangnya aktivitas masyarakat diluar rumah, berkurangnya kepercayaan masyarakat, serta sulitnya memperoleh bahan baku. Terutama UMKM masyarakat Kedinding. Strategi yang bisa di implementasikan oleh UMKM di Kedinding yaitu merubah model penjualan yang semula konvensional menjadi online atau ecommerce, melakukan suatu pemasaran digital dan membangun suatu branding untuk mengenalkan produknya, peningkatan kualitas produk maupun jasa demi kenyamanan serta menciptakan relasi kepada masyarakat maupun pelanggan agar tingkat kepercayaan konsumen meningkat. 


\section{KESIMPULAN}

Covid-19 merupakan wabah baru yang muncul di akhir tahun 2019. Wabah ini berasal dari Wuhan, China pertama kalinya. Wabah kali ini termasuk virus yang sangat berbahaya di karenakan virus yang tidak terlihat dan dapat mematikan banyak orang. Adanya virus ini tidak hanya berdampak pada kesehatan, melainkan juga kepada beberapa sektor di seluruh dunia. Bahkan sampai saat ini vaksin guna menangkal virus Covid-19 belum ditemukan. Dampak dari Covid-19 terhadap UMKM rata-rata mengalami penurunan omset yang lumayan besar. Hal ini terjadi karena berkurangnya aktivitas masyarakat diluar rumah, berkurangnya kepercayaan masyarakat, serta sulitnya memperoleh bahan baku. Terutama UMKM masyarakat Kedinding. Strategi yang bisa di implementasikan oleh UMKM di Kedinding yaitu merubah model penjualan yang semula konvensional menjadi online atau ecommerce, melakukan suatu pemasaran digital dan membangun suatu branding untuk mengenalkan produknya, peningkatan kualitas produk maupun jasa demi kenyamanan serta menciptakan relasi kepada masyarakat maupun pelanggan agar tingkat kepercayaan konsumen meningkat.

\section{DAFTAR PUSTAKA}

Awali, Husni dan Farida Rohmah, "Urgensi Pemanfaatan E-Marketing Pada Keberlangsungan UMKM Di Kota Pekalongan Di Tengah Dampak Covid-19" dalam Jurnal Ekonomi dan Bisis Islam, No. 1, Vol. 2, Janurari - Juni 2020.

Azizah, Nur, Fadilah, Igo Fadilah Ilham, Liza Putri Aqidah, Safira Aliyani Firdaus, Setyani Agung Dwi Astuti dan Imam Buchori, "Strategi UMKM untuk Meningkatkan

Perekonomian selama Pandemi Covid-19 pada saat New Normal", dalam OECONOMICUS Journal of Economics, No. 1, Vol. 05, December 2020.

Chafeey, Mayer, Internet marketing: Strategi, Implementation and Practice, Jakarta: Prentice hall/finansial times, 2009.

Fitriyani, Ika, Strategi Manajemen Bisnis Pasca Pandemi Covid-19, Jakarta: Press 2020.

Hamid, Suand, Edy, Ekonomi Indonesia dari Sentralisasi ke Desentralisasi, Ctk. Pertama, Yogyakarta: UII Press, 2006.

Ihza, Nur, Khofifah, Dampak Covid-19 Terhadap Usaha Mikro Kecil dan Menengah (UMKM), dalam Jurnal Inovasi Penelitian, No.7, Vol.1 Desember 2020.

Karyani, Rema, Manajemen Kampanye: Paduan Teoritis dan Praktis dalam Mengefektifkan Kampanye Komunikas, Bandung: Aambiosa Rekatam Media, 2004.

Karyani, Rema, Manajemen Kampanye: Paduan Teoritis dan Praktis dalam Mengefektifkan Kampanye Komunikasi, Bandung: Aambiosa Rekatam Media, 2004.

Kotler, Principles of Marketing 15th ed, (New Jersey: Prentice Hall Published, 2012. 
Lestari, The Effect Of Product Quality Toward Interest In. Journal of Business Studies (JOBS), Semarang: Jurusan Administasi Bisnis, Politeknik Negeri Semarang, 2019.

Masriansyah, Luki, "Go Digitial and Customer Relationship Marketing sebagai Strategi Pemulihan Bisnis UMKM yang Efektif dan Efisien di Masa Adaptasi New Normal" dalam Program Studi Magister Manajemen Fakultas Ekonomi dan Bisnis 2020

Mohammed, Internet Marketing: Building Advantage in a Network Economy, New York: McGraw-Hill Companies, 2003.

Nugroho, Adi, E-Commerce Memahami Perdagangan Modern di Dunia Maya, Bandung: Informatika bandung, 2013.

Pratiwi, Intan, Maya, "Dampak Covid-19 Terhadap Perlambatan Ekonomi Sektor UMKM" dalam Jurnal Ners, No. 2 Vol. 04, April 2020.

Purwana, Pemanfaatan Digital Marketing Bagi Usaha Mikro, Kecil, dan Menengah (UMKM) di Kelurahan Malaka Sari, Duren Sawit. Jurnal Pemberdayaan Masyarakat Madani (JPMM), 2017.

Rapitasari, "Digital marketing Berbasis Aplikasi Sebagai Strategi Meningkatkan Kepuasaan Pelanggan" dalam Jurnal Cakrawala, No.10 Vol Februari 2016.

Rohimah, "Era Digitalisasi Media Pemasaran Online dalam Gugurnya Pasar Ritel Konvensional. KANAL" dalam Jurnal Ilmu Komunikasi, No. 6 Vol. Februari 2009.

Rosita, Rahmi, "Pengaruh Pandemi Covid-19 Terhadap Umkm Di Indonesia”, dalam Jurnal Lentera Bisnis, No. 2, Vol. 09, November 2020.

S, Sukirno, Makro ekonomi Teori Pengantar, Jakarta: Rajawali Pers, 2016.

Setiawati, Pengaruh Strategi Pemasaran Online Terhadap Peningkatan Laba Umkm: Strategi Komunikasi Pemasaran, Bandung: Alfabeta, 2017.

Sulis, Hasil Wawancara dengan owner laundry, 03 Mei 2021.

Sumadi, "Menakar Dampak Fenomena Pandemi Covid-19 Terhadap Perbankan Syariah, dalam Jurnal hokum Ekonomi Syariah", No. 2, Vol. 3 Oktober 2020.

Supriatna, Eman, “Wabah Corona Virus Disease Covid 19 Dalam Pandangan Islam,” dalam Jurnal Sosial \& Budaya Syar'I, No. 01,Vol. Juni 2020.

Suyanto, M, Strategi Periklanan pada E-Commerce Perusahaan Top Dunia, Yogyakarta: andi. 200.

Tambunan,Tulus T.H, UMKM di Indonesia, Bogor: Ghalia Indonesia, 2009.

Thaha, Firdaus, Abdurrahman,“Dampak Covid-19 Terhadap Umkm Di Indonesia”, dalam Jurnal Brand, No. 1,Vol. 02, Juni 2020.

Triyono, Budi, Potret Belanja Online di Indonesia, (Jakarta: Pusat Data dan Sarana Informatika, 2013. 